\title{
Seasonal Behavior of a Shallow Estuary of the Lower Cauvery Basin, India
}

\author{
K.L. Priya, P. Jegathambal and E. J. James \\ Karunya University, Coimbatore
}

cross'ref http://dx.doi.org/10.5755/j01.erem.61.3.2041

(received in July 2012, accepted in September, 2012)

\begin{abstract}
The effect of bifurcation at the estuary mouth was studied on the measurements of salinity, current and tidal depth in a shallow estuary during spring and neap tides of two different seasons. There was a considerable variation of salinity at the observed stations during the seasons. At the shallowest location of the estuary, salinity, as high as $37 \mathrm{ppt}$, was observed during the period of zero fresh water discharge. The flushing time of the estuary was higher at its western side compared to the eastern one. The diffusion coefficient was reached by using an advection-diffusion equation. The estuary was classified using a circulation/stratification diagram. Well mixed conditions persisted during pre monsoon and post monsoon in the Muthupet estuary.

Keywords: Salinity, shallow estuary, bifurcating mouth, flushing time, diffusion coefficient, estuarine classification.
\end{abstract}

\section{Introduction}

In estuaries chemical, geological and biological transfers are dependent on their physical processes. Major processes such as mixing, circulation and transfer of materials are controlled by riverine fresh water flow, oceanic saline water flow, wind, waves, evaporation and rainfall, as the case may be. Seasonal variation of salinity and flushing time are probably caused by one or more of these processes, and attempts have been made to study them in many places of the estuarine environment. Kumari \& Rao 2009 reported the influence of fresh water flow on a diffusion coefficient where the latter was lower during the low fresh water discharge in the Godavary estuary. Dinesh \& Sarma 1991 observed that the flushing time recorded by means of a classical tidal prism method was lower than that obtained using a modified one. Alber \& Sheldon 1999 attempted to measure the influence of flushing time on the methods used for its calculation. Sheldon \& Alber 2006 evaluated the application of a fraction of both fresh water and tidal prism methods for determining the turn-over time. It was pointed out that a tidal prism method could be applied to estuaries with a smaller fresh water flow, while a fraction of the fresh water method could be used for estuaries with substantial flow. Dinesh \& Sarma 1999 obtained a lower diffusion coefficient at the mouth than near the river side in the Vashishti estuary. Jyothi et.al. 2000 observed seasonal fluctuation in the flushing time mainly due to the variation in the fresh water flow and topography of the Gauthami Godavari estuary. Other factors which affect the estuarine characteristics are bathymetry, size and shape of the estuary which are poorly understood. Estuary geomorphology has an impact on flushing time and salinity intrusion into it.

The Muthupet estuary, which forms a part of the Point Calimere Ramsar site, has experienced changes in geomorphologic characteristics during the past four decades. The estuary mouth has decreased from 1000 $\mathrm{m}$ to $400 \mathrm{~m}$. Due to reduction in water depth a new lagoon has been formed on the western side of the estuary. Before its formation, during the flood time the entire sea water used to enter the eastern estuary side. A new lagoon formation makes the saline flood water bifurcate into eastern and western directions. This may have an impact on the estuarine characteristics, resulting in the changes in its sediment transfer. To consider its sedimentation the estuary is to be characterized on the basis of its physical processes. Since the bifurcation effect on the estuarine characteristics is not thoroughly studied, we have attempted to examine it and its impact on both salinity intrusion inside the estuary and basic estuarine characteristics of a shallow lagoon under different 
fresh water flow conditions. As the estuary is a well mixed one, the coefficient of eddy diffusivity was obtained by solving a 1D advection diffusion equation. Dynamics of weakly stratified estuaries can be described by integrating a fluid equation over the cross sectional area (Uncles \& Redford 1980).

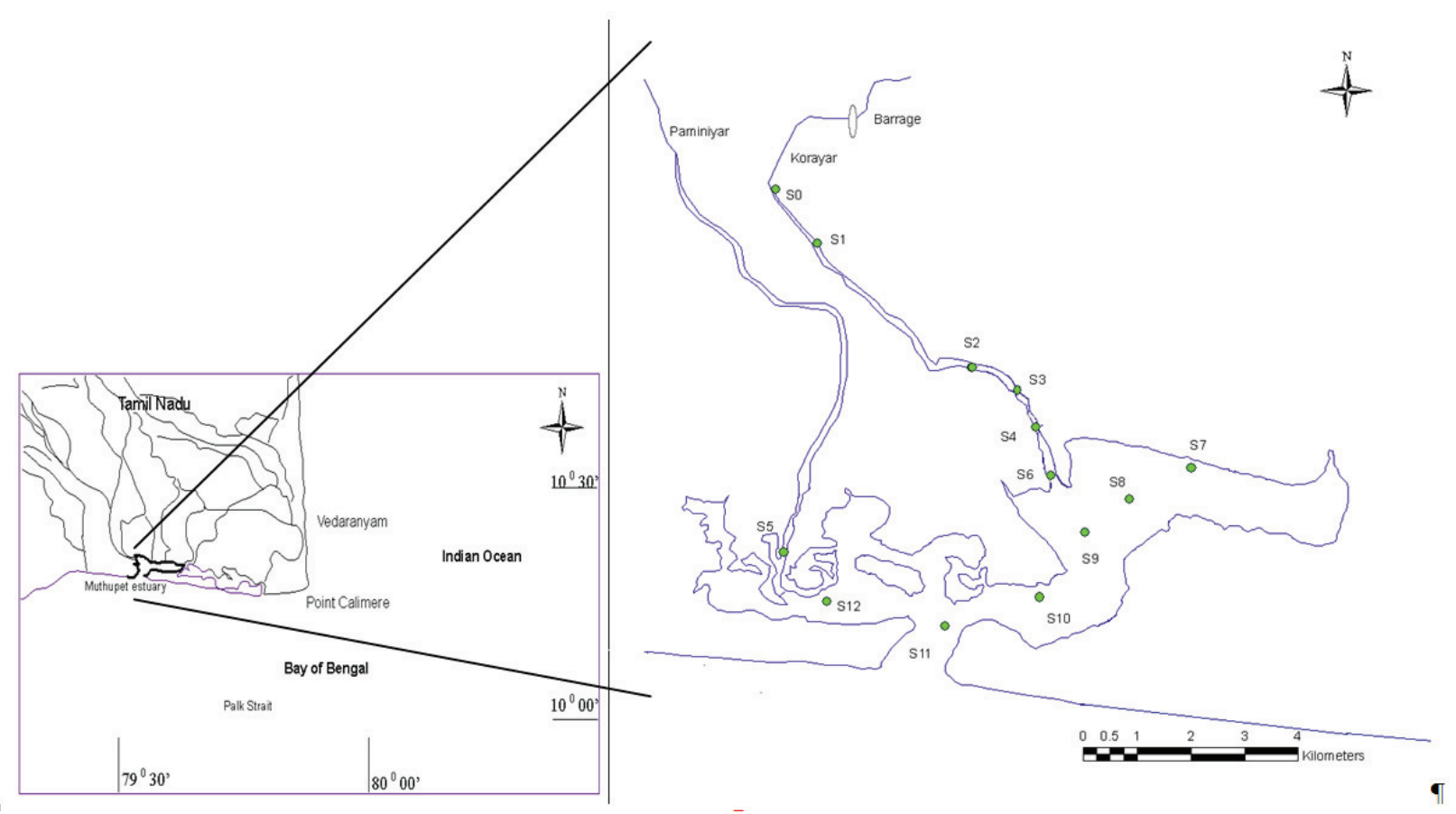

Fig. 1 .

Study area showing sampling stations

\section{Materials and Methods}

\subsection{Study Area}

The Cauvery river delta system discharges part of its water into the Palk Strait through its tributaries, namely the Korayar, the Paminiyar, the Kilathingyar, the Kandankurichiyar and the Marakakorayar. Prior to their discharge into the sea, the rivers form a small lagoon called Muthupet (Fig 1) with the water spread area of 18.35 sq.km (IRS PAN 2011). Even though five rivers join the lagoon, only the Paminiyar and the Korayar bring a considerable amount of fresh water. The lagoon is shallow, its average water depth being $1 \mathrm{~m}$, with the minimum depth of $0.2 \mathrm{~m}$ at the eastern side and the maximum of $1.8 \mathrm{~m}$ at the mouth. The lagoon is bordered by different mangrove species, Avicennia marina being dominant. The whole estuarine system, comprising the Paminiyar and the Korayar and the lagoon, has been considered to require basic characteristics, as there is no such study on a bifurcating estuary. The tides entering the mouth get divided into two - a part flowing east and a part flowing west. The Paminiyar is located in the west of the mouth, while the Korayar in the east. Out of the two rivers the Korayar carries more fresh water from the river Cauvery into the estuary. The other small rivers do not make much contribution to the fresh water flow into the lagoon. Bifurcation at the mouth may have an impact on salinity intrusion and hence on flushing time. In this regard not much of a study has been done. Thus, in this research an attempt has been made to understand a fraction of the tidal flow in the eastern and western directions.

\subsection{Collection of field data}

Field experiments were performed at stations S2 $\left(79^{\circ} 31^{\prime} 38^{\prime \prime} \mathrm{E}\right.$ and $\left.10^{\circ} 21^{\prime} 32^{\prime \prime} \mathrm{N}\right), \mathrm{S} 3\left(79^{\circ} 32^{\prime} 10^{\prime \prime} \mathrm{E}\right.$ and $\left.10^{\circ} 21^{\prime} 10^{\prime \prime} \mathrm{N}\right), \mathrm{S} 4\left(79^{\circ} 32^{\prime} 16^{\prime \prime} \mathrm{E}\right.$ and $10^{\circ} 20^{\prime} 56^{\prime \prime}$ $\mathrm{N})$, S5 $\left(79^{\circ} 35^{\prime} 46^{\prime \prime} \mathrm{E}\right.$ and $\left.10^{\circ} 19^{\prime} 41^{\prime \prime} \mathrm{N}\right)$, S6 $\left(79^{0}\right.$ $32^{\prime} 27^{\prime \prime} \mathrm{E}$ and $\left.10^{\circ} 20^{\prime} 25^{\prime \prime} \mathrm{N}\right), \mathrm{S} 7\left(79^{\circ} 33^{\prime} 45^{\prime \prime} \mathrm{E}\right.$ and $10^{\circ}$ $20 ' 32$ " N), S8 (79 $33^{\prime} 14^{\prime \prime} \mathrm{E}$ and $\left.10^{\circ} 20^{\prime} 13^{\prime \prime} \mathrm{N}\right), \mathrm{S} 9$ $\left(79^{\circ} 32^{\prime} 44^{\prime \prime} \mathrm{E}\right.$ and $\left.10^{\circ} 19^{\prime} 56^{\prime \prime} \mathrm{N}\right), \mathrm{S} 10\left(79^{\circ} 32^{\prime} 42^{\prime \prime} \mathrm{E}\right.$ and $\left.10^{\circ} 19^{\prime} 10^{\prime \prime} \mathrm{N}\right), \mathrm{S} 11$ ( $79^{\circ} 31^{\prime} 25^{\prime \prime} \mathrm{E}$ and $10^{\circ} 18^{\prime} 55^{\prime \prime}$ $\mathrm{N})$ and S12 (79 $30^{\prime} 10^{\prime \prime} \mathrm{E}$ and $\left.10^{\circ} 19^{\prime} 11^{\prime \prime} \mathrm{N}\right)$ during spring tides (January 2012 and March 2012) and during neap tides (February 2012 and March 2012) for a tidal cycle (Fig. 1). Horizontal current speed and direction at the station near the mouth (S11) were measured at two depths $(0.3 \mathrm{D}$ and $0.6 \mathrm{D}$; D being the water depth) every one hour using a Direct Reading Direction Finding current meter. At other stations, only the surface currents were measured, as the depth is less than $1 \mathrm{~m}$. The variation in water depth was monitored simultaneously at a 15 min interval and the water samples were collected at the same depths every $30 \mathrm{~min}$ from all stations. The samples were analyzed for salinity using a conductivity meter, after calibrating using the standard $\mathrm{KCl}$ solution of $0.01 \mathrm{~N}$. 

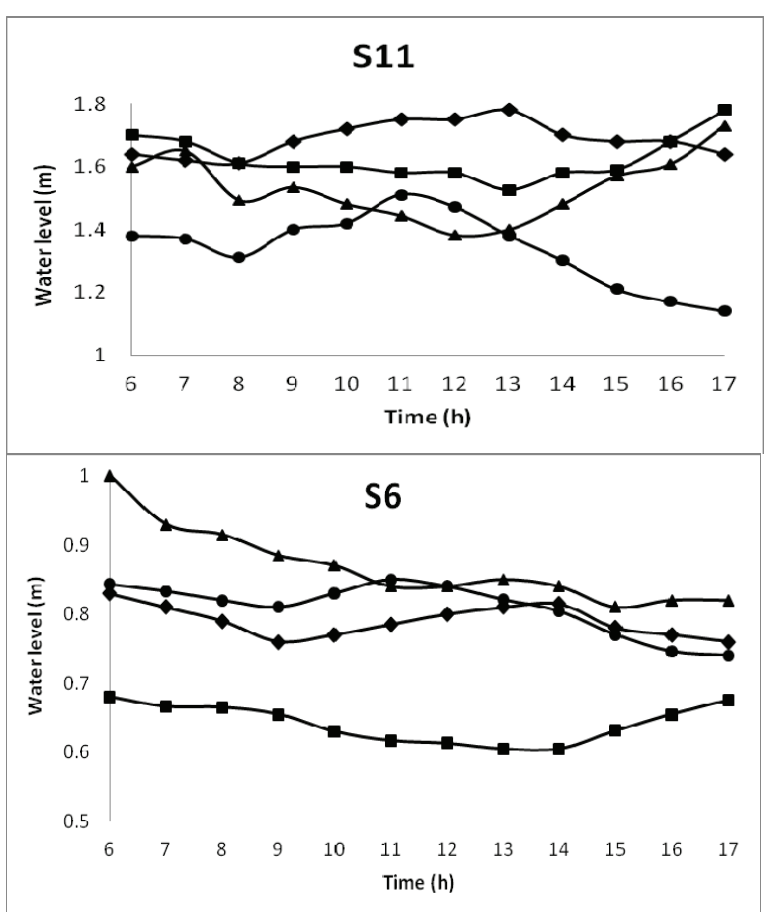

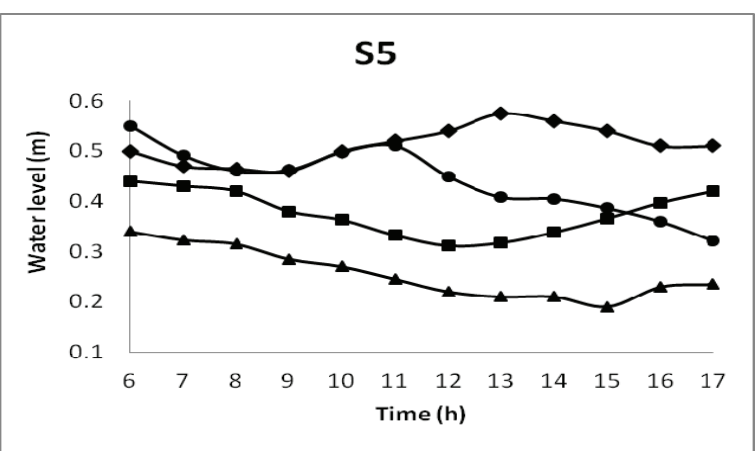

Post monsoon - spring tide

- Pre monsoon - spring tide

- Post monsoon - neap tide

Pre monsoon - neap tide

Fig. 2.

Tidal variations at sampling stations (a) S11, (b) S5 and (c) S6

\subsection{Estuarine characteristics}

Flushing time: Flushing time is the time required to replace a fraction of water in the estuary at a rate equal to river discharge (Dyer 1973; Bowden 1980; Ketchum 1983). Fresh water is considered as a tracer and it is the time taken to flush a parcel of water outside the mouth of the estuary. It is given by:

$T=\frac{Q}{R}$

where

Q - the total volume of fresh water accumulated in the estuary and

$\mathrm{R}-\quad$ river discharge.

The total volume of fresh water can be determined using,

$\mathrm{Q}=\sum \mathrm{f} \delta \mathrm{V}$

where

$\mathrm{f}-\quad$ the fraction of fresh water and

$\delta \mathrm{V}-$ the volume of the segment under consideration.

The fraction of fresh water is obtained from,

$\mathrm{f}=\frac{S_{0}-\mathrm{S}}{S_{0}}$

where

$\mathrm{S}_{0}-\quad$ salinity of sea water and
S - average salinity of the segment under consideration.

Diffusion coefficient: 1D Advection Diffusion equation was adopted to arrive at the diffusion coefficient as per:

$K=\frac{R * S}{A * \frac{d S}{d x}}$

where

$\mathrm{ds} / \mathrm{dx}$ - the longitudinal gradient of salinity (Arons \& Stommel, 1951)

A - the area of cross section of the channel.

\section{Results}

\subsection{Tidal Level variations}

Semi-diurnal tides predominated in the estuary. The latter is a micro-tidal estuary having the tidal range (difference between high-water and low-water levels during a tidal cycle) smaller than $1 \mathrm{~m}$ (Fig. 2 (a), (b) and (c)). A strong tidal asymmetry was experienced at landward station S6, where the ebb tide duration $(3 \mathrm{hr}$ and $4 \mathrm{hr}$, respectively) was higher than the flood tide duration (6 hr and $7 \mathrm{hr}$, respectively) during post monsoon and pre monsoon. At seaward station S11, the tidal asymmetry was weaker than that at landward stations. Topography, bifurcation at the mouth, shallow depth and geometrical shape are some of the reasons for tidal asymmetry at the landward stations. 


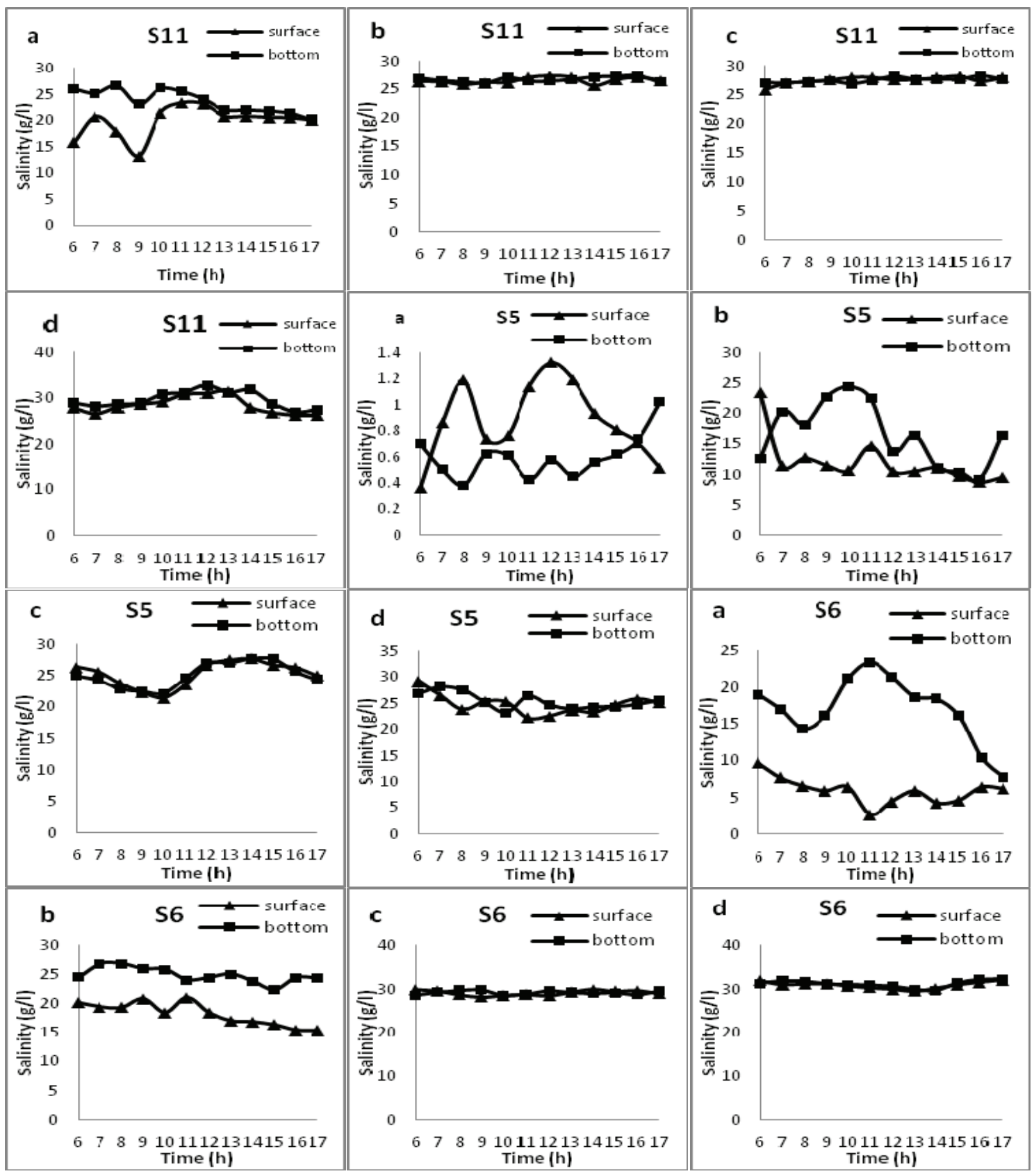

Fig. 3.

Salinity variations at the sampling stations during (a) post monsoon - spring tide, (b) post monsoon neap tide, (c) pre monsoon - spring tide and (d) pre monsoon - neap tide

\subsection{Salinity variations}

a. Post monsoon - spring tide (January 2012): Fresh water discharge from the Korayar and the Paminiyar rivers was 64 and 4 cumecs, respectively. Average salinity at station S11 was 22 ppt and ranged from 13 to 29 ppt during the tidal cycle (Fig. 3 a). Salinity at station S5 was much lower; average salinity being $0.7 \mathrm{ppt}$. This is attributed to fresh water discharge from the Paminiyar. Salinity at S6 ranged from $5 \mathrm{ppt}$ to $13 \mathrm{ppt}$ at the surface and 7 to $20 \mathrm{ppt}$ at the bottom. Fresh water discharge plays a significant role in estuary salinity. The vertical gradient of salinity has to be considered to render a better understanding of estuary dynamics. The vertical gradient arises due to the input of low density river water and high density sea water. Due to the density difference, a gravitational circulation occurs, where the denser sea water settles down and the lighter river water moves to the surface. Density current will be greater, when fresh water influx is high. The longitudinal gradient of salinity was appreciable during post monsoon (Fig. 4 a).

b. Post monsoon - neap tide (February 2012): Fresh water discharge from the Korayar river was 8 cumecs, while the discharge from the Paminiyar was nil. The salinity level was higher than that during the spring tide of post monsoon due to smaller fresh water discharge. Average salinity at station S11 was $26 \mathrm{ppt}$ (Fig. 3 b). Stratification of salinity was much smaller at S11. Tidal averaged salinity at station S6 was 22 ppt. The vertical gradient of salinity at S6 was appreciable due to fresh water discharge. Salinity levels at S5 ranged from $9 \mathrm{ppt}$ to $20 \mathrm{ppt}$, which were 
higher than during the previous measurements. This was attributed to reduction in fresh water discharge. Longitudinal variation of salinity was smaller because of reduction in fresh water discharge (Fig. 4 b).

c. Pre monsoon - spring tide (March 2012): There was no fresh water discharge from any of the rivers. Salinity levels reached as high as $35 \mathrm{ppt}$ at the landward station (Fig. 3 c). The estuary behaved as a well mixed estuary with a zero vertical gradient of salinity. Temporal variation of salinity was also insignificant. Salinity at the eastern side of the estuary was 7 ppt during post monsoon, while during pre monsoon it was as high as 37 ppt. Salinity was observed to be increasing with the distance from the sea mouth towards the eastern estuary side (Fig. 4 c). This was attributed to low fresh water discharge and excess evaporation resulting in the concentration of salinity at the eastern estuary side.

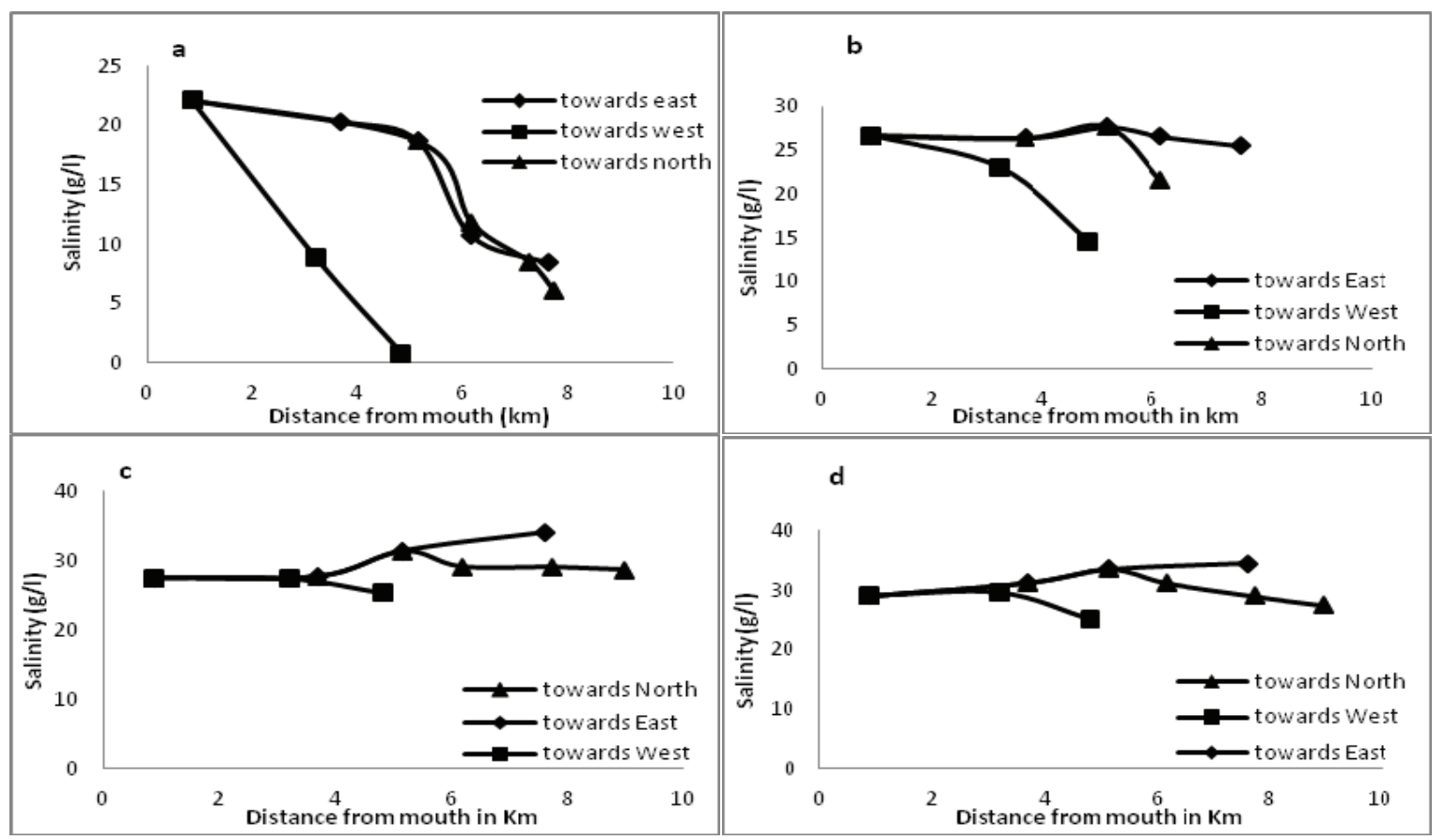

Fig. 4.

Longitudinal variation of salinity in northern direction, eastern direction and western direction during (a) Post monsoon - spring tide, (b) Post monsoon - neap tide, (c) Pre monsoon - spring tide and (d) Pre monsoon - neap tide

c. Pre monsoon - neap tide (March 2012): Salinity level reached the order of $37 \mathrm{ppt}$ at the eastern estuary side. Average salinity at S11 was 30 ppt and maximum salinity observed was 33 ppt (Fig. $3 \mathrm{~d})$. Tidal average salinity at S5 was $25 \mathrm{ppt}$ and at S6 - 30 ppt. The longitudinal gradient of salinity showed an increasing trend towards the eastern estuary side (Fig. 4 d).

\subsection{Current variations}

Current speed variations during the study are shown in Figs $5 \mathrm{a}, 5 \mathrm{~b}, 5 \mathrm{c}$ and $5 \mathrm{~d}$. The surface current was higher than that of the bottom. The tidal average current was higher at station S11 and decreased towards landward stations. The current was higher during the flood tide of a spring cycle, while during a neap cycle it was high during the ebb tide. A higher current speed during pre monsoon was evident compared to post monsoon.

Surface current ran towards the sea during the flood tide of post monsoon, while the bottom current flowed towards the land. During the ebb tide, seaward flow prevailed at both the surface and the bottom.
While during pre monsoon the landward flow prevailed at both the surface and the bottom during the flood tide and the seaward flow during the ebb tide. The maximum ebb current of $52 \mathrm{~cm} \mathrm{~s}^{-1}$ was recorded at S11 during the neap tide of the post monsoon season; while the maximum flood current of $45 \mathrm{~cm} \mathrm{~s}^{-1}$ during the spring tide of pre monsoon. The flood current was higher during pre monsoon than during post monsoon; during post monsoon the seaward flow of fresh water causes some shear, resulting in a decrease in the current speed of the flood tide.

Current speed at landward station S6 was as low as $1 \mathrm{~cm} \mathrm{~s}^{-1}$ during spring tide of post monsoon and during the flood phase of the tidal cycle. At a landward side, the effect of freshwater discharge was greater than at the seaward resulting in a decrease in the flood current. The average current at S6 was less than $30 \mathrm{~cm} \mathrm{~s}^{-1}$. The maximum current of $44 \mathrm{~cm} \mathrm{~s}^{-1}$ was recorded during the ebb tidal phase of neap cycle during pre monsoon. The flow of fresh water reduces net current speed during the flood tide, thereby enhancing salinity stratification. Station S5 recorded a very low current speed, less than $10 \mathrm{~cm} \mathrm{~s}^{-1}$. 


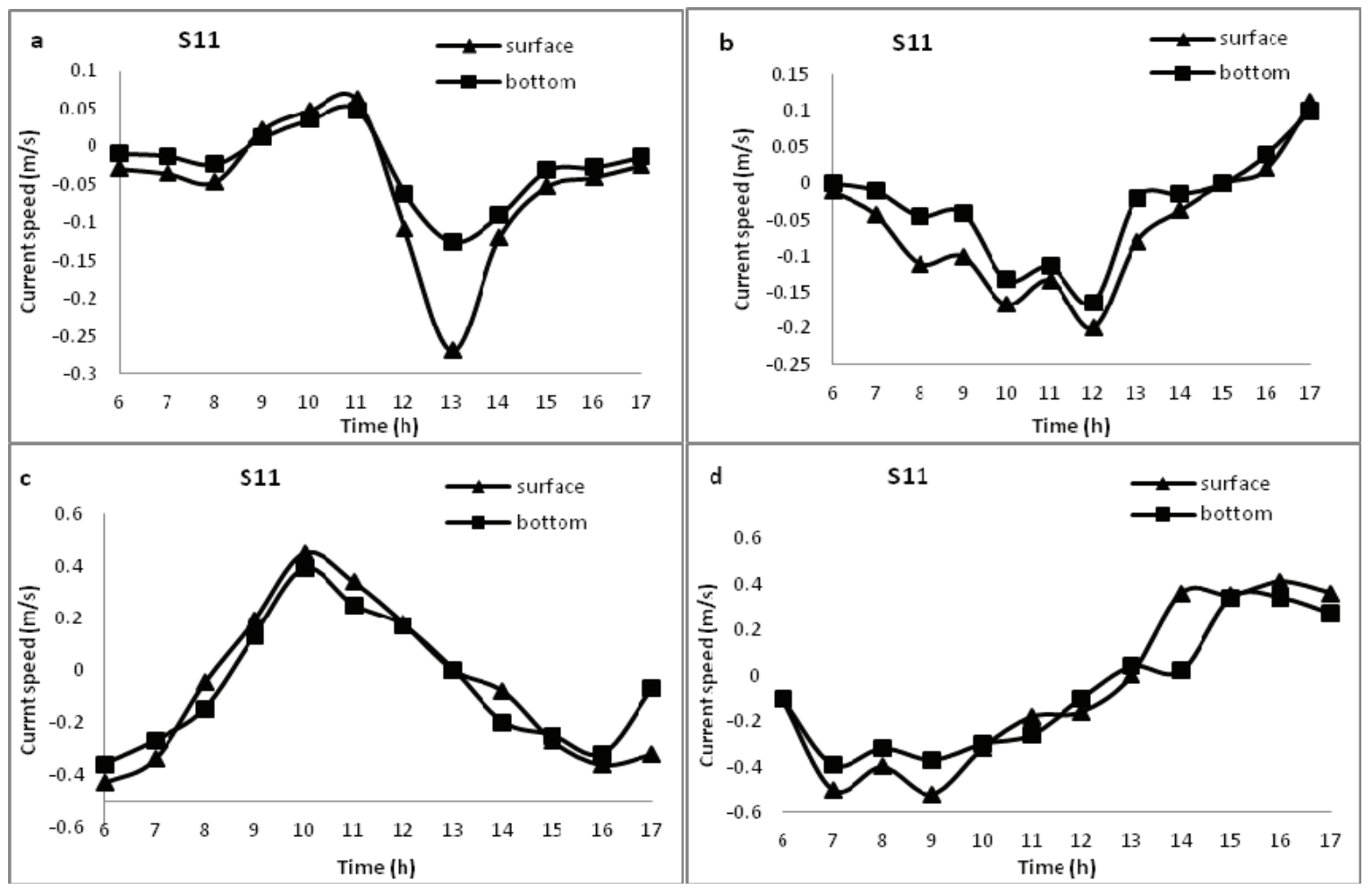

Fig. 5.

Current speed variations at S11 during (a) Post monsoon - spring tide, (b) Post monsoon - neap tide, (c) Pre monsoon - spring tide and (d) Pre monsoon-neap tide

Note: The current during flood tide is considered positive and that during ebb tide is considered negative.

\subsection{Estuarine characteristics}

Flushing Time: During post monsoon flushing time at the eastern and western side of the estuary was recorded as $10 \mathrm{hr} 31 \mathrm{~min}$ and 5 days $2 \mathrm{hr} 38 \mathrm{~min}$, respectively. Thus, the flushing time in the western direction is much higher as compared to the eastern side due to two reasons: (1) fresh water flow from the western side is smaller and (2) tidal flow in the western direction is smaller compared to the eastern side.

Diffusion Coefficient: A diffusion coefficient was obtained during the spring and neap tides of post monsoon. Fig. 6 gives the diffusion coefficient during post monsoon. As there was no fresh water flow during pre monsoon, the diffusion coefficient was not determined during pre monsoon.

A diffusion coefficient had a decreasing trend from the mouth towards the river end. A sudden increase in diffusion coefficient at station S6 (Fig. 6) may be attributed to the low cross sectional area, resulting in bigger diffusion of dissolved particles in water. The same trend was observed during the spring and neap tides. The diffusion coefficient was higher during the spring than neap tides. Two reasons were identified for its reduction during the neap tide: (1) fresh water discharge was smaller during spring than neap tides which had an impact on diffusion of the particles; (2) the spring tide is characterized by more dynamism due to higher current velocity in the estuary.

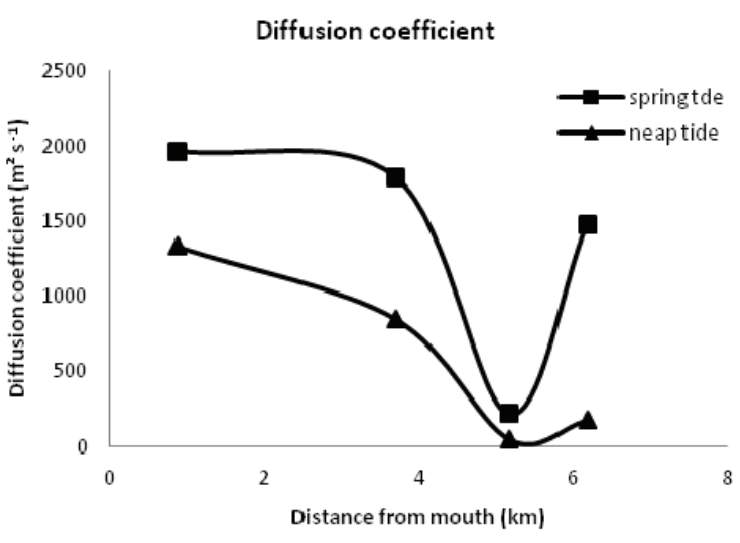

Fig. 6 .

Diffusion coefficient variation with the distance from the mouth

Estuarine Classification: The Muthupet estuary has been classified (Fig. 7) on the basis of the time averaged conditions according to a stratification/circulation diagram proposed by Hansen and Rattray 1966. The diagram is based on two dimensionless parameters, namely a stratification parameter (which gives information on the stratification level) and a circulation parameter (which is based on gravitational circulation). Stratification parameter $\delta \mathrm{S} / \mathrm{S}_{0}$ is the ratio of the difference between salinity at the bottom and surface to the depth average salinity. Circulation parameter $\mathrm{V}_{\mathrm{s}} / \mathrm{V}_{\mathrm{f}}$ is obtained from the ratio of current velocity at the surface to current velocity contributed by fluvial discharge. The contribution of fluvial discharge to current velocity is 
obtained from the mean river discharge and the cross sectional area. The Muthupet estuary has been classified as a well mixed estuary, showing no vertical salinity stratification during pre monsoon and post monsoon. The stratification parameter was lower during pre monsoon than during post monsoon.

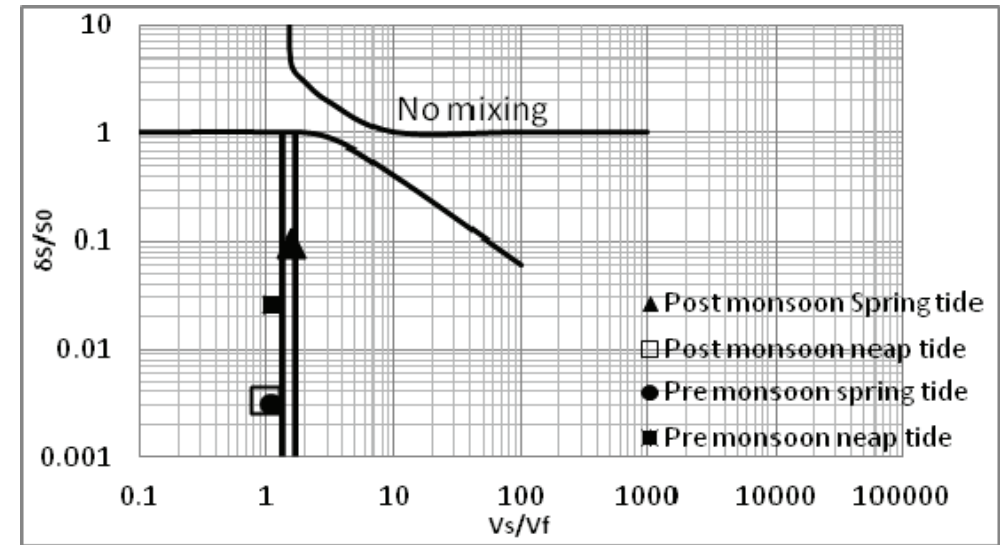

Fig. 7. Classification of Muthupet estuary

\section{Conclusions}

The Muthupet estuary is peculiar in having distinct characteristics at its mouth due to bifurcation of incoming flood water from the sea. Due to its geometrical shape, $80 \%$ of the tidal water finds its path to the eastern side, while the remaining $20 \%$ enters its western side. As such, the flushing characteristics of the estuary differ at its eastern and western portions; the western side having more flushing time than the eastern one. Salinity dynamics was mainly controlled by the fresh water flow; when the latter ceased, no temporal and spatial variation of salinity was observed. The eastern side of the estuary experienced salinity levels as high as 37 ppt during the time of zero fresh water discharge due to shallowness, thereby enhancing more evaporation. The estuary has been classified as a well mixed estuary during post monsoon and pre monsoon, based on Hansen and Rattray classification diagram.

\section{References}

Alber, M. \& Sheldon, J. E., Trends in salinities and flushing times of Georgia estuaries, Proceedings of the 1999 Georgia water resources conference, University of Georgia, March 30-31, 1999.

Arons, A. B. \& Stommel, H., A mixing length theory of tidal flushing, Trans Am. Geophys. Union, 32, 1951, pp. 419.

Bowden, K. F., Physical features, salinity, temperature, circulation and mixing processes, In; Chemistry and biogeology of estuaries E. edited by
Olaussion \& I. Cato, John Wiley \& Sons, New York, 1980, pp. $37-70$.

Dinesh, P. K. K., Sarma, R. V. \& Zingde, M. D., Freshwater flushing time scales of the Vashishti estyary, West Coast of India, Intern. J. Environ. Studies, 56, 1999, pp. 313-323.

Dinesh, P. K. K., Sarma, R. V., Josanto, V., Flushing characteristics of Amba estuary, west coast of India, Ind. J. Mar. Sci., 20, 1991, pp. 212 - 215. http://dx.doi.org/10.1080/00207239908711207

Dyer, K. R., Estuaries: A physical introduction, Wiley \& Sons, London, 1973, pp. 140.

Hansen, O. V. \& Rattray, Jr. M., New dimensions in estuarine classification, Limnology and Oceanography, 11, 1966, $\quad$ pp. $\quad 319 \quad 326$. http://dx.doi.org/10.4319/1o.1966.11.3.0319

Jyothi, D., Murthy, T. V. R., Sarma, V. V., Rao, D. P., Computation of diffusion coefficients for waters of Gauthami Godavari estuary using one dimensional advection-diffusion model, Ind. J. Mar. Sci., 29, 2000, pp. $185-187$.

Ketchum, B. H., Estuarine Characteristics, In: Estuaries and Enclosed Seas Ecosystem of the World, Series 26, Ketchum B. H. eds., Elsevier Scientific Publishing company, Oxford, 1983, pp. $1-14$.

Kumari, V. R. \& Rao, I. M., Estuarine characteristics of lower Krishna river, Indain Journal of Marine Sciences, 38 (2), 2009, pp. 215-223.

Sheldon, J. E. \& Alber, M.,The calculation of estuarine turnover times using freshwater fraction and tidal prism models: A critical evaluation, Estuaries and Coasts, 29(1), 2006, pp. 133 - 146.

Uncles, R. J. \& Redford, Seasonal and spring-neap tidal dependence of axial dispersion coefficients in Severna wide vertically mixed estuary, J Fluid Mech., 98, 1980, pp. $703 \quad-\quad 726$. http://dx.doi.org/10.1017/S0022112080000353 
K.L. Priya - Assistant Professor, School of Civil Engineering, Karunya University.

Main research area: Estuarine Dynamics, Estuarine Sedimentation, Groundwater quality

Address: $\quad$ Coimbatore 641114,

Tamil Nadu, India

Tel.: $\quad 04222614450$

Fax: $\quad 914222615615$

E-mail: $\quad$ klpriyaram@gmail.com
P. Jegathambal - Professor, Water Institute, Karunya University.

Main research area: Groundwater Hydrology, Water

Resources Engineering, Water Treatment

Address: $\quad$ Coimbatore 641114,

Tamil Nadu, India

Tel.:

04222614479

Fax: $\quad 914222615615$

E-mail: $\quad$ esther.jegatha@gmail.com

E. J. James - Director (Water Institute) and Dean (Research) Karunya University.

Main Research Area: Hydrology, Water Resources

Engineering, Estuarine Dynamics, Wetland

Management, Coastal Engineering

Address: $\quad$ Coimbatore 641114,

T|el.: $\quad 04222614478$

Fax: $\quad 914222615615$

E-mail: $\quad$ ejjames@karunya.edu

\title{
Žemojo Kaverio Baseino Indijoje sekliųjų (upès) žiočių sezoniškumo ịvertinimas
}

\author{
K.L. Priya, P. Jegathambal and E. J. James
}

(gauta 2012 m. liepos mèn., priimta spaudai 2012 m. rugsèjo mèn.)

Upès žiočių (estuarijų) išsiskyrimo i dvi šakas reiškinys buvo tyrinëjamas druskingumo matavimais, srovių ir potvynių gylių matavimais sekliose žiotyse vykstant pavasario ir dviejų skirtingų sezonų potvyniams ir atoslūgiams. Sezono metu nustatytose vietose buvo pastebėtas žymus druskingumo pokytis. Sekliausioje žiočių vietose buvo nustatytas aukštas druskingumas (37 ppt), kai nebuvo gèlo vandens pritekejjimo. Žiočių nuplovimo laikas (vandens tėkmės greitis ) vakarinejje pusejje buvo didesnis, palyginti su rytine. Difuzijos koeficientas buvo apskaičiuotas naudojantis difuzijos lygtimi. Žiotys buvo vertinamos naudojant cirkuliacijos ir stratifikacijos diagramas. Kintančios oro sąlygos Muthupet estuarijoje išlieka visus metus. 